\title{
СВГЕН КОНОВАЛЕЦЬ І УКРАЇНСЬКА СТРІЛЕЦЬКА БРИГАДА В НІМЕЦЬКОМУ ЯБЛОННОМУ
}

\author{
Іван XОМА \\ Національний університет "Львівська політехніка" \\ кафедра історії, музеєзнавства і культурної спадщини \\ вул. Митрополита Андрея, 3, Львів, 79013, Україна \\ e-mail: khomaivan@ukr.net
}

\begin{abstract}
До маловідомої сторінки діяльности полковника $€$. Коновальця належить остання формальна посада в армії УНР - командир Української стрілецької бригади в Німецькому Яблонному. Це припадає на березень - липень 1920 р. Цей період $є$ визначальним на етапі переходу від військової до політичної діяльности. Адже завдання, які були поставлені в умовах становища армії УНР на весну 1920 р., можна було виконати тільки політичним шляхом. Однак через дуже складні взаємини між політичним керівництвом УНР та ЗУНР Є. Коновальцю не вдалося організувати військову частину з інтернованих.

Ключові слова: Євген Коновалець, Українська стрілецька бригада в Чехо-Словаччині, українська військова еміграція.
\end{abstract}

Ставлення проблеми. Традиційно в науково-популярній та науковій літературі дослідники пишуть, що після того як у грудні 1919 р. розформовано Групу Січових Стрільців, наступним етапом діяльности $Є$. Коновальця стала Українська Військова Організація. Однак створенню УВО передував табір для інтернованих у Луцьку ${ }^{1}$ та спроба формально й неформально очолити Українську стрілецьку бригаду в Німецькому Яблонному, громадсько-політична робота у Празі та Відні з різними українськими політичними середовищами тощо. У студії, на основі вперше введених до наукового обігу джерельних матеріялів, досліджено діяльність $Є$. Коновальця на посаді командира Української стрілецької бригади в Німецькому Яблонному, яка була його останньою офіційною посадою в лавах армії УНР. Також тут ідеться про політичні виклики, з якими зіткнувся Є. Коновалець на цьому етапі служби в армії УНР.

На початку березня 1920 р. С. Коновалець, після двох з половиною місяців перебування в таборі для інтернованих у Луцьку, отримав дозвіл на виїзд до Варшави. 5 березня, свої повноваження керівника Української залоги м. Луцька, передав Р. Сушкові².

Відтак 10 березня Р. Сушко вивіз усіх січових стрільців, чисельністю 160 старшин та 380 стрільців, з Луцька, через Львів до Ланцута ${ }^{3}$. Частину стрільців

\footnotetext{
${ }^{1}$ Іван Хома, Свген Коновалець у Луцькому таборі для інтернованих (грудень 1919 - березень 1920 рр.). Історико-культурні студії. Вип. 5. Ч.1., (2018): 43-46.

${ }^{2}$ Корпус Київських Січових стрільців, Archiwum im. Tarasa Shewczenki, Biblioteka Narodowa w Warszawie, M/f. 92256, 878 str.

${ }^{3}$ Переїзд Січових Стрільців через Львів. Вперед. 11 березня (1920): 4. 
ISSN 2078-6077. Наукові зошити історичного факультету Львівського університету. 2020. Випуск 21. Proceedings of History Faculty of Lviv University. 2021. Issue 20.

долучили до 6-ї Стрілецької дивізії під командуванням М. Безручка. У тій дивізії 31 березня Р. Сушка призначили командиром 16 бригади. Інша частина стрільців повернулись у Галичину або переїхали до Чехо-Словаччини.

Дня 16 березня 1920 р. Є. Коновальця було підвищено до ранги полковника та призначено на посаду начальника бригади в Німецькому Яблонному, А. Мельника призначили військовим аташе УНР у Чехо-Словаччині, а 1 квітня Ю. Отмарштайна призначили начальником штабу бригади 4

Відтак 5 квітня, за підписом В.о. голови Ради Народних Міністрів А. Лівицького, вийшла постанова асигнувати 5 млн австрійських корон для організації та утримання Української стрілецької бригади в Чехо-Словаччині, а також перевезення ії в Україну. У постанові зазначено, щоб гроші видати Є. Коновальцеві ${ }^{5}$.

3 Варшави Є. Коновалець виїхав до Відня. 3 перших листів до нього дізнаємося, що він оселився в готелі Huberthof, за адресою Wien VIII, Josefstadter Strasse, 22. А. Мельник поїхав до Праги. Окрім них, до Відня та Праги виїхали I. Даньків, Ю. Отмарштайн, Р. Дашкевич, В. Кучабський, І. Андрух, М. Матчак, Я. Чиж, В. Чорній та інші 6 . За розпорядженням А. Мельника їх записали до військово-санітарної місії УНР ${ }^{7}$.

Є. Коновалець та Стрілецька рада розраховували, що вони, як вихідці 3 Галичини, зможуть переконати командування бригади в Німецькому Яблонному про необхідність продовжити війну з більшовиками. На це розраховував $\mathrm{i}$ С. Петлюра. На квітень 1920 р. сумніву в тому, що вдасться організувати цю бригаду не було. Табір бригади був розташований приблизно за 135 км на пн.$c x$. від Праги, біля кордону з Німеччиною, та приблизно за 26 км на захід від містечка Ліберець, де розташовувалась інша частина українських військовиків Галицької Армії.

В. Бень був один із тих представників оточення С. Петлюри, 3 ким через листи спілкувався Є. Коновалець. 25 квітня В. Бень інформував, що 22 квітня Польща визнала самостійність УНР, уряд УНР уклав договір із Польщею про звільнення Правобережжя від більшовиків, 6-та Стрілецька дивізія вирушила на фронт, а вони виїжджають в Україну 27 квітня. Далі він пише, що на Великодні свята у Львові бачився з Р. Сушком та І. Даньковим, які просять надіслати інформацію та інструкцію, також згадує про УГА, яка участи в боях не брала i,

\footnotetext{
4 Ярослав Тинченко, Офічерський корпус Армії Украӥнської Народної Республіки (19171921). (Наукове видання. Київ: Темпора, 2007), 213, 276, 320.

${ }_{5}^{5}$ Директорія, Рада Народних Міністрів Української Народної Республіки. Листопад 1918 листопад 1920 pp. (Док. і матеріали. У 2-х томах, 3-х частинах. Том 2. Київ: Видавництво імені Олени Теліги, 2016), 613.

${ }^{6}$ Свген Коновалець, Причинки до історіїукраїнської революиії. (Львів: Громадське об’ єднання “Нова хвиля”, 2002), 46.

${ }^{7}$ Михайло Ковальчук, На чолі Січових Стрільців. Військово-політична діяльність Свгена Коновальия в 1917-1921 pp. (Київ: Українська видавнича спілка імені Ю. Липи, 2010), 146.
} 
мабуть, не буде. Окремо, відзначає, що в УГА діють більшовицькі “чрезвичайки”, які контролюють старшин. Покликаючись на січового стрільця В. Соловчука, інформує, що Н. Гірняк, І. Рогульський та М. Бісик утекли з Вінниці до Ю. Тютюника. Пише, що немає інформації про М. Омеляновича-Павленка, але натомість дивізія О. Удовиченка “дійсно представляє силу”.

Щодо надій, які покладались на бригаду Є. Коновальця, то В. Бень пише: "Вашу бригаду всі чекають як на спасіння. Головний отаман сказав передати Вам, щоби вжити заходів для одержання зброї для бригади і набоїв. Головний отаман пропонує по цій справі переговорити з послом Славінським"”. Насамкінець В. Бень запитав, чи отримали гроші на формування бригади, а також підвів підсумок, що “пляни дуже гарні (на майбутнє), но чи буде відвага їх перевести життя, ото вопрос!”".

У листі від 27 квітня В. Бень акцент уваги зосередив на інформації, що Є. Коновалець та А. Мельник “тільки заігривають”, а бригади в Україну не пустять. В. Беню цю інформацію повідомив П. Лисенко. В. Бень, зокрема, пише, що він у присутності С. Петлюри, П. Лисенка та інших заявив: “Доля Г.О. є долею Січового стрілецтва. Отаман Коновалець і отаман Мельник вірять, що Г.О. має на думці одно: незалежна демократична народна республіка! I до вже переведення цієї думки в життя вони всі підуть з Г.О.”

Складно однозначно дати відповідь, що стало підставою для таких розмов. У попередньому листі В. Беня немає навіть натяку на недовіру. Очевидно, що ці розмови викликала укладена між УНР та Польщею 21-24 квітня 1920 р. Варшавська угода. Мабуть, це було певним застереженням, що з огляду на долю Галичини за результатом укладеної угоди, організована з галичан бригада може не вирушити в Україну або Стрілецька рада відмовиться підтримувати Головного отамана.

Відсутність бригади з Чехо-Словаччини під командуванням Є. Коновальця, посилювала підозру про змову проти С. Петлюри. У Києві, 3 якого польські війська вибили 7 травня 1920 р. більшовиків, М. Курах згадує, як М. Безручко повідомив його, що $Є$. Коновалець налаштований скинути С. Петлюру та очолити націоналістичний рух. Також М. Курах згадував, що, коли він говорив 3 С. Петлюрою, той звинувачував $€$. Коновальця в намірах його скинути та очолити уряд ${ }^{11}$.

8 Лист В. Беня. Осередок украӥнської культури і освіти (Вінніпет, Канада). Архіви. Фонд Євгена Коновальия № 307/19. Течка 6/1.

* Славінський М. очолював дипломатичну місію УНР у Чехо-Словаччині.

9 Лист В. Беня. Осередок української культури і освіти (Вінніпег”, Канада). Архіви. Фонд Євгена Коновальия № 307/19. Течка 6/1.

${ }^{10}$ Лист В. Беня. Осередок української культури і освіти (Вінніпет”, Канада). Архіви. Фонд Євгена Коновальия № 307/19. Течка 6/2.

${ }^{11}$ Михайло Ковальчук, На чолі Січових Стрільців. Військово-політична діяльність Свгена Коновальия в 1917-1921 рр. (Київ: Українська видавнича спілка імені Ю. Липи, 2010), 143-145. 
ISSN 2078-6077. Наукові зошити історичного факультету Львівського університету. 2020. Випуск 21. Proceedings of History Faculty of Lviv University. 2021. Issue 20.

3 іншого боку, стрілецьке середовище, що керувало 6-ю Стрілецькою дивізією, бувши переповнене емоціями повернення в Україну, особливо до Києва, прийняло ухвалу готуватись до відновлення формації Січових стрільців. Р. Сушко закликав Є. Коновальця терміново повертатися в Україну. 4 червня М. Безручко писав Є. Коновальцю, що 6-та Стрілецька дивізія продовжує формуватися та очікує його приїзду з бригадою ${ }^{12}$.

Дня 4 червня з Києва лист $Є$. Коновальцеві надіслав і рідний брат Степан. Пише, щоб скоріше приїжджав, бо багато людей на нього чекає ${ }^{13}$.

У той час у Відні та Празі Є. Коновалець, А. Мельник та інші члени Стрілецької ради зіткнулися з новими викликами. 3 цього приводу, Є. Коновалець пише: “. ...побачили, що наші сподівання найти сприятливі умови для праці були великим непорозумінням. Антагонізм поміж галичанами й наддніпрянцями, що постав після грудневої угоди Української Народної Республіки з Польщею та поглибшав після квітневої умови, нагадував настрої на Наддніпрянщині після переходу Галицької Армії до Денікіна. Тільки тепер галичани обвинувачували наддніпрянців..."14.

Стрілецьку раду не оминули різні підозри та звинувачення в зраді. Оточення Є. Петрушевича вважало іiі членів наддніпрянцями, а наддніпрянські військові та політичні кола - галичанами. Зі слів Є. Коновальця, “наддніпрянські кола, що були приклонниками польсько-української згоди, включно з Головним Отаманом, почали дивитися на нас скоса, закидаючи нам, що ми ставимося дуже негативно до польсько-українських залицянь”. Керівництво ЗУНР натомість вважало, що $€$. Коновалець та його оточення є “....польськими запроданцями й що Українську Бригаду хочемо передати в руки поляків" ${ }^{\prime 2}$.

Є. Коновалець та А. Мельник не вважали С. Петлюру зрадником. Про це коротко йдеться у повідомленні А. Мельника до С. Коновальця 28 травня 1920 р., яке він передав з Праги до Відня через директора Українського пресового бюро у Відні О. Кущака. А. Мельник інформує, що секретар закордонної делегації УПСР О. Жуковський підписав декларацію, де йшлося про Головного отамана, як зрадника і про потребу його усунути ${ }^{16}$.

3 повідомлення А. Мельника також виходить, що робота, яка дала б можливість узятися до командування Українською бригадою в Німецькому Яблонному продовжувалась. Також А. Мельник порушив проблему фінансування участи осередку “Сокола” при бригаді в VII-му “Всесокільському

\footnotetext{
${ }^{12}$ Михайло Ковальчук, На чолі Січових Стрільиів. Військово-політична діяльність Свгена Коновальия в 1917-1921 pp. (Київ: Українська видавнича спілка імені Ю. Липи, 2010), 143-144.

${ }^{13}$ Лист С. Коновальия. Осередок української культури і освіти (Вінніпег”, Канада). Архіви. Фонд Євгена Коновальия № 307/19. Течка 18/1.

${ }^{14}$ Свген Коновалець, Причинки до історії украӥнської революиії. (Львів: Громадське об’ єднання “Нова Хвиля", 2002), 46.

${ }^{15}$ Там само, 46-47.

16 Лист А. Мельника. Осередок украйнської культури і освіти (Вінніпет”, Канада). Архіви. Фонд Євгена Коновальия № 307/19. Течка 13/14.
} 
здвизі”, який мав відбутися в Празі в 20-х числах червня 1920 р. Він писав Є. Коновальцеві: “Якщо я завтра 29 мая не буду мати конкретні відповіді про фінансування сокільського злету, комітет в неділю буде змушений віднестись до Чехів 3 відмовою. Лишає всего лише 20 днів і тим самим так чи інакше справа упадає”. А. Мельник просив Є. Коновальця 29 травня об 11 год чекати в готелі, де мешкає, його телефонного дзвінка. ${ }^{17}$

Дня 29 травня, після телефонної розмови, А. Мельник надіслав $€$. Коновальцеві ще одне повідомлення: “Зробіть все можливе, щоби добути гроші на фінансовання злету сокільського. Я не представляю собі погубних наслідків, що понесе за собою відмова наша участи. Тому прийміть всі міри"18.

Відомо, що через брак фінансування, товариство “Сокіл” Української бригади участи в "Всесокільському здвизі” не взяло. І. Боберський зумів забезпечити присутність лише представників від українського сокільського руху під керівництвом С. Смаль-Стоцького ${ }^{19}$.

Попри різні спроби наблизитись до бригади, Є. Коновальцеві не вдалося замінити чинного командира бригада А. Вариводу. Хоча бригада в той час себе позиціонувала частиною армії УНР, але негативно сприймала військовополітичний союз з Польщею ${ }^{20}$.

$€$. Коновалець у своїх спогадах не оминув увагою обставини, що склались навколо формування бригади станом на кінець квітня-травень 1920 р. Пише, що президент Є. Петрушевич покладав на неї великі надії, як на "військо Східної Галичини" і нізащо не хотів зрікатися свого впливу на неї. У самій бригаді думка про переїзд в Україну, як узагалі про виїзд із Чехо-Словаччини, була дуже непопулярною. Влада Чехо-Словаччини також не погоджувала виїзд бригади, вимагаючи узгодити цю проблему з Польщею. Поразка спільних польськоукраїнських військ у війні з більшовицькою Росією, за словами Є. Коновальця, “... зробили наш плян неактуальним. Ми рішили його ліквідувати”21.

Отже, в такій системі відносин українського еміграційного середовища квітнячервня 1920 р. проходила діяльність $С$. Коновальця та команди Стрілецької ради у Празі та Відні. Варшавська угода, яка істотно поглибить протистояння між політичним проводом УНР та ЗУНР, позбавила можливости Є. Коновальця, А. Мельника та інших членів Стрілецької ради сформувати нове військове з'єднання української армії та розпочати виконувати бойові завдання на окупованій більшовиками УНР.

17 Лист А. Мельника. Осередок украӥнської культури і освіти (Вінніпег”, Канада). Архіви. Фонд Євгена Коновальия № 307/19. Течка 13/14.

${ }^{18}$ Лист А. Мельника. Осередок украӥнської культури і освіти (Вінніпег”, Канада). Архіви. Фонд Євгена Коновальия № 307/19. Течка 13/2.

${ }^{19}$ Симон Наріжний, Украӥнська емітрачія: культурна праия украӥнської емітрачії між двома світовими війнами, (Прага, 1942), 273.

20 Заява української бригади в Чехії, Вперед. 25 травня (1920), 2; Укр. бригада в Нім. Яблоннім, Громадська Думка. 24 травня (1920), 1.

${ }^{21}$ Свген Коновалець, Причинки до історії украӥнської революиї̈, (Львів: Громадське об’ єднання "Нова хвиля“, 2002), 47. 
ISSN 2078-6077. Наукові зошити історичного факультету Львівського університету. 2020. Випуск 21. Proceedings of History Faculty of Lviv University. 2021. Issue 20.

Одночасно у Відні $€$. Коновалець, крім пошуку допомоги у встановленні контактів з інтернованими УГА в Німецькому Яблонному, пробує формувати нове військове з'єднання залучивши полонених українців, що перебували в різних европейських державах. Щоб залучити українських полонених в Італії, він контактував 3 українським дипломатичним представником в Італії В. Бандрівським. 16 травня 1920 р. В. Бандрівський, який приїхав до Відня і не застав тоді $€$. Коновальця, повідомляє його, що “не знаю нічого про се (докладно ні про реальні основи, на яких сі плани побудовані, ні про способи якими їх хочеш зреалізувати, ні про політплатформу, з якою твою акцію задумуєш зв'язати". Пише, однак, що може допомогти в трьох напрямках: сприяти Є. Коновальцеві у поїздці до Італії; поцікавитись у відповідних людей цим питанням; спробувати самостійно його вивчити. Якщо така допомога цікавить, то просить Є. Коновальця повідомити ${ }^{22}$.

Дня 14 червня I. Андрух, член Стрілецької ради, спробував розвіяти ілюзії щодо залучення військовополонених українців, більшість із яких перебувала в Німеччині та Італії, та формувати з них нове військове з'єднання української армії, щоб вести війну з більшовиками. І. Андрух зауважує, що Є. Коновалець не орієнтується в настроях та політичних переконаннях військовополонених. Вважає, що навіть полонені галичани, які намучились у польських таборах, готові заради помсти продовжувати воювати з поляками, але не 3 більшовиками, яких вони можуть розглядати союзниками, але не ворогами. Навіть якщо вдасться переконати, що воювати проти поляків можна буде тоді, коли сформується сильна армія на території УНР, то достатньо відредагованої відозви чи одного агітатора, щоб уся проведена робота була знівельована. Тому радить не марнувати на це часу $^{23}$. На початку липня 1920 р. І. Андрух перебував у Кошицях серед інтернованих двох українських армій. У місті та околицях перебувало тоді багато колишніх січових стрільців ${ }^{24}$.

Після успішного контрнаступу армії більшовицької Росії проти союзних польсько-українських військ Є. Коновальцеві надійшла аналітична довідка “Положення на Наддніпрянщині і в Галичині”. Довідка, автор якої не вказав свого прізвища, написана 25 червня у Львові, завершується такими словами: "Петлюру ніщо вже не врятує. Найкраще було б, коли б він зреагнував (відмовився від посади $-I . X$.), а на його місце прийшов хтось більш авторитетний, котрий міг би числити на послух і жертвенність мас; Українська бригада в Чехо-Словаччині, перевезена на Наддніпрянщину, мало спричинилась би до скріплення збройної сили, а нам випав би з рук важкий атут (козир $-I$. $X$.)

22 Лист В. Бандрівського. Осередок украӥнської культури і освіти (Вінніпег”, Канада). Архіви. Фонд Євгена Коновальия № 307/19. Течка 14/1.

${ }^{23}$ Михайло Ковальчук, На чолі Січових Стрільців. Військово-політична діяльність Свгена Коновальия в 1917-1921 pp. (Київ: Українська видавнича спілка імені Ю. Липи, 2010), 146-147.

${ }^{24}$ Лист М.Талпаша. Осередок украӥнської культури і освіти (Вінніпег”, Канада). Архіви. Фонд Євгена Коновальия № 307/19. Течка 5/1. 
у хвилі перевороту. Тому найкраще бригади не рухати, а підождати на дальший розвиток подій”. Ішлося про те, що коли Червона армія вступить у Галичину, туди повинна зайти і Українська бригада, можливо, навіть під червоним прапором, для захисту “прав українського народу та взяти в оборону нашу інтелігенцію, котра буде переслідувана і за "зраду" Галицької Армії, і за свою “контрреволюційність”. Це треба буде зробити тому, що галицька інтелігенція та селянські маси серйозно думають про спасіння від поляків за допомогою більшовиків. На переконання автора довідки, такий напрям політичної орієнтації формує середовище $Є$. Петрушевича у Відні, яке відірване від життя і не знає, що таке більшовизм ${ }^{25}$.

Приблизно в той самий час $€$. Коновалець отримав лист зі Львова від сотника УГА Р. Стельмахова. Лист написано 26 червня. Р. Стельмахів, покликаючись на знайомство ще “від цьоці Адамковоі”', висловлює намір “розказати про всі настрої, ферменти та навіть події, щоб могли тим легше виробити собі лінію якою Вам ступати". Шкодує, що не мав змоги побачитись з С. Коновальцем коли той був у Львові, однак не вказує, коли точно це було. У листі інформує, хто у Львові з українців підтримував союз з Польщею та успішні спільні військові дії на території УНР. Однак останні події в Україні, на його думку, є фатальними для С. Петлюри і уряду. Відзначає, що Омелянович-Павленко, який би мав мати сильнішу армію, ніж поляки, “не той чоловік, на якого жде Україна. Він добряга, та без стратегії, ініціятиви і ширшого світогляду”. Щодо інтернованих українців у Чехо-Словаччині пише, що "шкода видавати на Україну, бо прийде зима, то тиф і зимно знову зїдять його”. Цю думку підкріплює тим, що більшовицькі війська перейшли в контрнаступ проти польсько-українських військ. У цій ситуації необхідно зберегти якусь частину і вичекати час. Звернув увагу $€$. Коновальця на його спроби очолити українські військові сили в Чехо-Словаччині: “Чому Ви, пане Геню, до переговорів із бригадою Вариводи не пішлете якого галичанина. Ви ж рахуєтесь в галичан за наддніпрянця. Ужийте до того якого мудрого галицького старшину, який знає галицьку психіку то справа піде добре“. Одночасно закликав, "Ви, пане Генко, вдартеся в груди і скажіть собі, що Ви також ту завинили, бо припустили дві нагоди, щоб справу повести добре. Раз Ви не пішли з СС на Львів, щоб створити собі вікно до Европи, і мали б базу, з якою би можна було вести всі операції і роздобувати односторої, а друге Ви могли тих спереляканих поляків давно задусити і Україну звільнити від фантастичноакробатичних штук, а не зробили сего..."26.

Інформація про військову ситуацію на території УНР та в Галичині, нереалізовані зусилля очолити бригаду в Німецькому Яблонному, настрої українських полонених та інтернованих у таборах, а також низка інших питань,

25 Звідомлення про військово-політичну ситуацію в Україні у червні 1920 р. (Військовоісторичний альманах. Ч.2. 2007), 136-141.

${ }^{26}$ Лист Р. Стельмахова. Осередок української культури і освіти (Вінніпел”, Канада). Архіви. Фонд Євгена Коновальия № 307/19. Течка 34/1. 
ISSN 2078-6077. Наукові зошити історичного факультету Львівського університету. 2020. Випуск 21. Proceedings of History Faculty of Lviv University. 2021. Issue 20.

потребували підвести підсумки та визначитись, що робити далі. Фактично Є. Коновалець та січові стрільці, що перебували в Празі та Відні, були вилучені з військово-політичного процесу. Складається враження, що командування армії УНР на них уже не розраховувало.

У зв'язку з цим на початку липня $Є$. Коновалець з Відня їде до Праги, де жили та працювали А. Мельник, М. Матчак, Я. Чиж, В. Кучабський та інші січові стрільці. Січовий стрілець М. Талпаш, який перебував у Кошицях, 5 липня надіслав $€$. Коновальцеві лист до Праги на адресу української місії. Повідомляє, що “всі наші, які є в Кошицях та околиці сподіваються втекти в Галичину ... но сам Андрух каже мені тут остати поки і мати з Вами зв'язок"27.

У Празі в липні 1920 р. відбулось засідання Стрілецької ради, на якому за словами Є. Коновальця, “після 3'ясування безкорисности й безцільности дальшого перебування за кордоном, рішили ми закликати всіх Січових Стрільців до повороту в Галичину. Після цього засідання Стрілецької Ради перестала фактично існувати Січово-Стрілецька Організація. Старшини Січових Стрільців, що були за кордоном, здебільшого роз'їхалися, - одні на Наддніпрянщину, інші до Галичини. Там стали вони такими самими громадянами, як усі інші. Кожний з них вступив до тієї групи чи партії, що краще відповідала його особистим переконанням"28.

Точна дата засідання Стрілецької ради не відома. Зі світлини, що подано в матеріялі 3. Книша до книги "Свген Коновалець та його доба", випливає, що участь у засіданні брали Є. Коновалець, I. Андрух, М. Матчак, Я. Чиж, І. Чмола та В. Кучабський ${ }^{29}$. I. Андрух, який перебував у Кошицях, прибув на засідання. Однак відсутній А. Мельник, який працював у місії УНР у Празі, а також був членом ревізійної комісії “Українського Клубу”зо. Можливо, засідання Стрілецької ради відбулось у час відрядження А. Мельника до Берліна, про повернення 3 якого він інформував $С$. Коновальця 21 липня, який тоді ще був у Празіз ${ }^{31}$.

Відтак 2-3 серпня 1920 р. в Празі в ширшому колі українських військових середовищ відбувся “З'їд відпоручників українських військових частин i організацій за кордоном”. Серед присутніх були представники Української бригади в Німецькому Яблонному (не офіційно), Українського союзу старшин у Відні, Українського Клубу в Празі, українських військових робітничих сотень із Закарпаття, української еміграції в США та інші ${ }^{32}$. За результатом роботи з'їзд

${ }^{27}$ Лист М. Талпаша. Осередок української культури і освіти (Вінніпет”, Канада). Архіви. Фонд Євгена Коновальия № 307/19. Течка 5/1.

${ }^{28}$ Свген Коновалець, Причинки до історії української революиії. (Львів: Громадське об’єднання "Нова Хвиля", 2002), 47.

29 Зеновій Книш, Начальна команда УВО у Львові. (Свген Коновалець та його доба. Мюнхен, 1974), 290

${ }^{30}$ Вісти з еміграції, Громадська Думка. 15 липня (1920), 2.

${ }^{31}$ Лист А.Мельника. Осередок украӥнської культури і освіти (Вінніпег”, Канада). Архіви. Фонд Євгена Коновальия № 307/19. Течка 13/3.

${ }^{32}$ Свген Коновалець, Причинки до історії украӥнської революиії. (Львів: Громадське об’ єднання “Нова Хвиля”, 2002), 48; Військовий з'їзд в Празі, “Громадська Думка”. 16 серпня (1920), 1. 
ухвалив: 1. 3'їзд стоїть на позиції повної соборности та самостійности України, без різниці, в яку соціяльну та політичну форму переросте самостійність; 2. 3 'їзд стверджує, що сучасне катастрофічне становище є наслідком нестійкости, хитання, суперечностей із гаслами щодо самостійности та соборности, а також існування трьох українських урядів (УНР, ЗУНР та УСРР); 3. З’їзд вважає вказаним не чинити мілітарного спротиву з'єднанню українських земель, яке зараз наспіває через більшовицький наступ, та одночасно закликає всіх старшин і стрільців української армії до подальшої послідовної боротьби за самостійність України; 4. 3'їзд вважає за необхідне зберегти в організованій формі наявні за межами України військові частини та об'єднати їх ідейно між собою на засадах самостійности та соборности; 5. Закликати стрільців та старшин, щоб вони по можливості виїжджали на Україну для зміцнення організаційних сил, необхідних боротьбі за самостійність та соборність; 6. 3'їзд обрав комісію для створення військового комітету, який мав б очолити провід над усіма частинами i організаціями за кордоном; 7. 3 'їзд визнає Український союз старшин потрібною організацією, професійною, але рекомендує змінити назву та статут, щоб членами могли ставати не тільки старшини; 8. 3'їзд доручає Українському союзові старшин відстоювати необхідність підтримки та допомоги українським воякам перед урядами УНР та ЗУНР. До комісії були включені Т. Рожанківський, Я. Чиж та П. Меркун ${ }^{33}$.

Після з'їзду один із членів Стрілецької ради виїхав до С. Петлюри 3 пропозицією звільнити українську армію від “ії незавидної ролі оборони Галичини для Польщі та заховати Армію, що боролася на правому крилі польського фронту, у Карпати й таким робом ухилитися тимчасово від дальшої боротьби проти большевиків". Вони розраховували, що більшовики після перемоги над Польщею стали б загрозою для Антанти. Це започаткувало б організацію фронту проти більшовиків. Тоді би звернули увагу на українські військові сили, яким не хотіли допомагати. Українська армія стала б частиною великого антибільшовицького фронту. С. Петлюра не підтримав цю пропозицію ${ }^{34}$.

Оцінку цій ініціятиві дав дослідник М. Ковальчук. На його думку, перспектива успішно зреалізувати цей план виглядає сумнівною. По-перше, відступ української армії в Карпати навряд чи зміг би істотно вплинути на становище на фронті. По-друге, польське командування було добре поінформоване військовою розвідкою, що старшини і вояки армії УНР не відчувають особливого пієтету до своїх союзників. Тому від серпня 1920 р. деякі польські воєначальники i представники цивільної адміністрації постійно очікували “зради” з боку армії УНР й готувалися до такого розвитку подій. По-третє, умови прикарпатського

\footnotetext{
${ }_{33}$ Ухвала “3'їду відпоручників українських військових частин і організацій за кордоном”. Осередок української культури і освіти (Вінніпет”, Канада). Архіви. Фонд Євгена Коновальця № 307/19. Течка 47/1.

${ }^{34}$ Свген Коновалець, Причинки до історії украйнської революиїі, (Львів: Громадське об’єднання “Нова Хвиля”, 2002), 48.
} 
ISSN 2078-6077. Наукові зошити історичного факультету Львівського університету. 2020. Випуск 21. Proceedings of History Faculty of Lviv University. 2021. Issue 20.

регіону були не надто сприятливі для довготривалої оборони проти будь-якого противника. По-четверте, армія УНР могла б лише деякий час протриматися в карпатському регіоні, бо відносини між українськими військовиками і галицьким населенням були в цей час далеко не найкращими.

У серпні 1920 р. Є. Коновалець розірвав відносини з урядом УНР. Про це він доповідав на засіданні Стрілецької ради 11 вересня 1921 р. У протоколі записано: "Коли Українські війська, переступивши Збруч, боронили Галичину перед большевиками для поляків - запротестовано супроти цього перед урядом УНР і зірвано зносини". ${ }^{35}$ Його подальша боротьба за відродження української державности носить політичний характер.

Отже, останнє офіційне місце служби полковника Є. Коновальця в армії УНР командир Української стрілецької бригади в Німецькому Яблонному (ЧехоСловаччина). Це втягнуло його в політичне протистояння між двома українськими державними центрами УНР та ЗУНР, бо бригада й надалі політично підпорядковувалась диктаторові ЗУНР Є. Петрушевичу. Після підписання Варшавського договору Є. Коновальцеві так і не вдалось безпосередньо приступити до командування бригадою та перевести іï в підпорядкування армії УНР. Після цих декількох місяців військово-політичної діяльности щодо організації Української стрілецької бригади Є. Коновалець покине лави армії УНР та почне шукати нові форми боротьби за відродження української державности.

\title{
YEVHEN KONOVALETS AND UKRAINIAN RIFLE BRIGADE IN GERMAN YABLONNE
}

\author{
Ivan KHOMA \\ Lviv Polytechnic National University \\ Department of History, Museum Studies and Cultural Heritage \\ 3 Mytropolyt Andrei str., Lviv, 79013, Ukraine \\ e-mail: khomaivan@ukr.net
}

The little-known page of the activity of the colonel Ye. Konovalets is his last official position in the Army of the Ukrainian People's Republic, which was the commander of the Ukrainian rifle brigade in German Yablonne in March-July 1920. This period is decisive in the phase of transition from his military activity to political one. However, Ye. Konovalets failed to organize a military unit due to very difficult relationship between political leaders of the Ukrainian People's Republic and Western Ukrainian People's Republic.

Traditionally, in scientific and popular literature, researchers write about the establishment of the Ukrainian military organization under the leadership of Ye. Konovalets in Prague in July 1920.

The paper analyses political challenges which Ye. Konovalets met at this stage of his service in the army. In particular, Ye. Konovalets and the Counsil of Sich Riflemen understood the they would be

${ }^{35}$ Олександр Кучерук, Протокол засідання Стрілецької ради 10-12 вересня 1921, (Воєнна історія. № 1, 2002), 138. 
able to convince the command of the brigade in German Yablonne to continue the war with the Bolsheviks. This was also expected by S. Petliura. There was no doubt that it would be possible to organize this brigade in April 1920. The brigade camp was located approximately $135 \mathrm{~km}$ to the northeast from Prague, near the border of Germany.

However, Ye. Konovalets, A. Melnyk and other members of the Counsil of Sich Riflemen faced new challenges in Vienna and Prague. On this occasion, Ye. Konovalets wrote: “...we saw that our expectations to find favorable conditions for our work were a big misunderstanding".

Despite different attempts to approach to the brigade, Ye. Konovalets could not replace the acting commander of the brigade A. Varyvoda. Although the brigade considered itself as the part of the Army of the Ukrainian People's Republic at that time.

As a result, Ye. Konovalets ended his relations with the Government of the Ukrainian People's Republic in August 1920. His further struggle for the revival of Ukrainian statehood had political character.

Key worlds: Ye. Konovalets, Ukrainian rifle brigade in German Yablonne, Ukrainian military emigration.

\section{REFERENCES}

Khoma, Ivan. Yevgen Konovalets in the Lutsk camp for the internists (december 1919 march 1920). Historical and Cultural Studies, No. 5, (2018): 43-46. (in Ukrainian)

Korpus Kyyivs ${ }^{1}$ kykh Sichovykh stril'tsiv, Archives Taras Shevchenko, National Library in Warsaw, M/f. 92256, 878 p. (in Poland)

Crossing the Sichovykh Stril ${ }^{1}$ tsiv through Lviv. Vpered. 11 March (1920): 4. (in Ukrainian)

Tynchenko, Yaroslav. Officer Corps of the Army of the Ukrainian People's Republic (19171921). Scientific publication Kyiv: Tempora, 2007, 213, 276, 320. (in Ukrainian)

Directorate, Council of People's Ministers of the Ukrainian People's Republic. November 1918-November 1920. Docs and Materials in 2 volumes, 3 parts, volume 2. Kiev: Publishing House named after Olena Teligi, 2016, 613. (in Ukrainian)

Konovalets, Yevgen. Cause to the history of the Ukrainian revolution. Lviv: Public Association "Nova khvylya", 2002. (in Ukrainian)

Kovalchuk, Mykhaylo. At the head of the Sichovykh Stril tisiv. Military-political activity of Yevhen Konovalets in 1917-1921. Kyiv: Ukrainian Publishing Union named after Y. Lipi, 2010, 146. (in Ukrainian)

Letter by V. Benya. The Ukrainian Culture and Education Center (Winnipeg, Canada). Archives Yevhen Konovalets Foundation No. 307/19. Folder 6/1. (in Ukrainian)

Letter by V. Benya. The Ukrainian Culture and Education Center (Winnipeg, Canada). Archives Yevhen Konovalets Foundation No. 307/19. Folder 6/2. (in Ukrainian)

Letter by S. Konovalets. The Ukrainian Culture and Education Center (Winnipeg, Canada). Archives Yevhen Konovalets Foundation No. 307/19. Folder 18/1. (in Ukrainian)

Letter by A. Melnyk. The Ukrainian Culture and Education Center (Winnipeg, Canada). Archives Yevhen Konovalets Foundation No. 307/19. Folder 13/2. (in Ukrainian)

Letter by A. Melnyk. The Ukrainian Culture and Education Center (Winnipeg, Canada). Archives Yevhen Konovalets Foundation No. 307/19. Folder 13/14. (in Ukrainian)

Narizhnyy, Symon. Ukrainian emigration: cultural work of Ukrainian emigration between two world wars, (Prague, 1942). 273. (in Ukrainian)

Statement by the Ukrainian Brigade in the Czech Republic. Vpered. May 25 (1920): 2. (in Ukrainian) 
ISSN 2078-6077. Наукові зошити історичного факультету Львівського університету. 2020. Випуск 21. Proceedings of History Faculty of Lviv University. 2021. Issue 20.

Ukr Brigade in Ger. Yablonne. Hromads ${ }^{1}$ ka Dumka. 24 May (1920), 1. (in Ukrainian)

Letter by V. Bandrivskoho. The Ukrainian Culture and Education Center (Winnipeg, Canada). Archives Yevhen Konovalets Foundation No. 307/19. Folder 14/1. (in Ukrainian)

Letter by M. Talpasha. The Ukrainian Culture and Education Center (Winnipeg, Canada). Archives Yevhen Konovalets Foundation No. 307/19. Folder 5/1. (in Ukrainian)

Report on the military-political situation in Ukraine in June 1920. Military Historical Almanac, June No. 2, 2007: 136-141. (in Ukrainian)

Letter R. Stelmakhiva. The Ukrainian Culture and Education Center (Winnipeg, Canada). Archives Yevhen Konovalets Foundation No. 307/19. Folder 34/1. (in Ukrainian)

Knysh, Zenoviy, UMO Primary team in Lviv. (Yevhen Konovalets and his period, Munich, (1974): 290. (in Ukrainian)

News from emigration, Hromads ${ }^{1}$ ka Dumka. July 15 (1920): 2. (in Ukrainian)

Letter by A. Melnyk. The Ukrainian Culture and Education Center (Winnipeg, Canada). Archives Yevhen Konovalets Foundation No. 307/19. Folder 13/3. (in Ukrainian)

Decision of the "Congress of the vidporuchnykiv of Ukrainian military units and organizations abroad”, The Ukrainian Culture and Education Center (Winnipeg, Canada). Archives Yevhen Konovalets Foundation No. 307/19. Folder 47/1. (in Ukrainian)

Kucheruk, Oleksandr, Protokol of the meeting of the Strilets ${ }^{1}$ koyi rady September 10-12, 1921. Military History, No. 1, 2002: 138. (in Ukrainian) 